\title{
REVITALISASI BANK SAMPAH SEKOLAH DALAM MENDESAIN MODEL PENDIDIKAN LINGKUNGAN BERKELANJUTAN BERBASIS TEKNOLOGI TEPAT GUNA
}

\author{
Budiaman $^{1}$, Aam Amaningsih Jumhur ${ }^{2}$, Ahmad Kholil $^{3}$, Astri Febry Susanti ${ }^{4}$ \\ ${ }^{1}$ Program Studi Pendidikan IPS Universitas Negeri Jakarta \\ ${ }^{2}$ Program Studi Pendidikan Teknik Mesin Universitas Negeri Jakarta \\ ${ }^{3}$ Program Studi Pendidikan Teknik Mesin Universitas Negeri Jakarta \\ ${ }^{4}$ Program Studi Pendidikan IPS Universitas Negeri Jakarta \\ E-mail:budiaman@unj.ac.id, aamamaningsihjumhur@unj.ac.id, \\ ahmadkholil@unj.ac.id, astrifebrys@gmail.com
}

\begin{abstract}
This Integrated Community Service Activity Real Work Lecture aims to revitalize school waste banks in designing sustainable environmental education models based on appropriate technology. Environmental education is expected to be obtained by junior high school students through the waste bank extracurricular program. Environmental education to be achieved is focused on managing and utilizing waste to produce environmental products into strategic activities that can be developed, in collaboration with successful waste banks. The method of implementation is in the form of observation and FGD conducted in SMP Negeri 9 and SMP Negeri 21 Bekasi City. Through this activity, various problems experienced by SMP Negeri 9 and SMP Negeri 21 Bekasi City were formulated in re-activating the school waste bank program. Based on the series of activities from FGD to simulation, it can be concluded that school leaders, environmental extracurricular coaches, and students of SMP Negeri 9 and SMP Negeri 21 Bekasi City really hope that waste management activities in their respective schools can be reactivated. Considering that the activities are still in a pandemic atmosphere, the reactivation of the school waste bank is carried out in conjunction with the restructuring of the extracurricular environmental management in their respective schools.
\end{abstract}

Keywords: revitalization; waste bank; environmental awareness; appropriate technology

\begin{abstract}
Abstrak
Kegiatan Pengabdian Kepada Masyarakat Terintegrasi Kuliah Kerja Nyata ini bertujuan untuk melakukan revitalisasi bank sampah sekolah dalam mendesain model pendidikan lingkungan berkelanjutan berbasis teknologi tepat guna. Pendidikan lingkungan diharapkan dapat diperoleh oleh siswa SMP melalui program ekstrakulikuler bank sampah. Pendidikan lingkungan yang ingin dicapai difokuskan pada pengelolaan dan pemanfaatan sampah sampai menghasilkan produk lingkungan menjadi kegiatan strategis yang dapat dikembangkan, bekerjasama dengan bank sampah yang sudah sukses. Metode pelaksanaan berupa observasi dan FGD yang dilakukan di SMP Negeri 9 dan SMP Negeri 21 Kota Bekasi. Melalui kegiatan ini dirumuskan berbagai permasalahan yang dialami oleh SMP Negeri 9 dan SMP Negeri 21 Kota Bekasi dalam mengaktifkan kembali program bank samapah sekolah. Berdasarkan rangkaian kegiatan dari mulai FGD sampai simulasi dapat disimpulkan bahwa pimpinan sekolah, Pembina ekstrakulikuler lingkungan, dan siswa SMP Negeri 9 dan SMP Negeri 21 Kota Bekasi sangat berharap agar kegiatan pengelolaan sampah di sekolah masing-masing dapat diaktifkan kembali. Mengingat kegiatan masih dalam suasana pandemi maka pengaktifan kembali bank sampah sekolah dilakukan bersamaan dengan restukturisasi pengurus ektrakulikuler lingkungan di sekolah masing-masing.
\end{abstract}


Kata Kunci: revitalisasi, bank sampah, kesadaran lingkungan, teknologi tepat guna.

\section{PENDAHULUAN}

Permasalahan sampah sampai saat ini masih menjadi persoalan pelik yang belum dapat diselesaikan secara tuntas. Di beberapa tempat, masih ditemukan penumpukan sampah, terutama di pekarangan kosong, di fasilitas umum perumahan, dan pinggiran pasar. Beberapa musibah yang diakibatkan oleh penumpukan sampah saat penghujan seperti banjir dan dan pencemaran lingkungan membawa dampak buruk bagi masyarakat sekitar. Fenomena perubahan lingkungan pada akhir-akhir ini menjadi suatu kejadian yang menyentak pemikiran kita. Beberapa kejadian musibah yang diakibatkan menurunnya kualitas lingkungan menyebabkan kita melakukan refleksi dan menghubungkan berbagai kejadian tersebut dengan proses pendidikan lingkungan selama ini. Permasalahan lingkungan yang diakibatkan oleh banyaknya penggunaan kendaraan bermotor, kesadaran masyarakat yang rendah terhadap lingkungan, dan penyimpangan perilaku, secara masih dapat menurunkan kualitas lingkungan.

Kota Bekasi memiliki pengelolaan dan pemrosesan sampah di TPA Sumur Baru, Kecamatan Bantargebang. TPA ini memiliki luas sekitar 12,4 hektar. Dari 5 zona yang ada, sudah 4 zona yang ditutup akibat urugan sampah sudah menggunung dengan sekitar 10 hektar. Saat ini yang masih berfungsi adalah zona 5 dengan luas sekitar 2,4 hektar. Direncanakan akan ada pembebasan lahan untuk zona 6, 7 dan 8 .
Menurut Yudiyanto

Sampah merupakan material sisa yang tidak diinginkan setelah berakhirnya suatu proses. Sampah didefinisikan oleh manusia menurut derajat keterpakaiannya, dalam proses-proses alam sebenarnya tidak ada konsep sampah, yang ada hanya produkproduk yang dihasilkan setelah dan selama proses alam tersebut berlangsung. Akan tetapi karena dalam kehidupan manusia didefinisikan konsep lingkungan maka sampah dapat dibagi menurut jenisjenisnya dan dikumpulkan. Sampah yang telah terkumpul harus diangkut ke tempat pembuangan sampah. Nugraha (2010) mengatakan bahwa "maksud tempat buangan sampah adalah tempat pembuangan sampah terakhir setelah dikumpulkannnya dari tempat-tempat pengumpulan".

Volume sampah Kota Bekasi mencapai 2.286,625 $\mathrm{m}^{3}$ per hari. Dengan jumlah penduduk mencapai 2.554.499 jiwa (2013) diperkirakan sampah yang dihasilkan per jiwa per orang mencapai $0,64 \mathrm{~kg}$ per orang per hari. Sementara itu layanan pengangkutan sampah yang dilakukan oleh Dinas Kebersihan Kota Bekasi baru mampu melayani tidak lebih dari 55,45\%. Itu artinya ada sekitar 44,25\% sampah masih berserakan di Kota Bekasi setiap harinya. Jika dikalkulasikan maka sampah yang terangkut ke TPA Sumurbatu setiap harinya hanya sebanyak $914.650 \mathrm{~kg}$ per hari atau hanya melayani sampah warga Kota Bekasi sebanyak 1.416.470 jiwa. Pentingnya kesadaran akan lingkungan 
dapat dibentuk melalui pendidikan lingkungan berkelanjutan.

Berkaitan dengan pengembangan model pendidikan lingkungan, guru memiliki andil dalam upaya mengoptimalkan pengelolaan sekolah berbasis lingkungan. Tema sekolah berbasis lingkungan menjadi tren baru dalam kegiatan pengelolaan lembagalembaga pendidikan di berbagai wilayah Indonesia, dengan mengangkat kepedulian siswa terhadap kebersihan, keindahan, dan upaya-upaya pemeliharaan lingkungan hidup, baik di dalam maupun di sekitar sekolah. Usaha mengembangkan kepedulian tersebut tidak lain karena dewasa ini keperdulian masyarakat terhadap lingkungan fisik di sekitar kita sangat rendah. Dengan demikian akan berpengaruh pula terhadap kondisi lingkungan baik secara fisik maupun sosial budaya.

Kondisi lingkungan di sekitar sekolah merupakan sumber belajar sehingga dapat menjadi bahan desain model pendidikan lingkungan berkelanjutan. Semua mata pelajaran dapat dikaitkan dengan sisipan materi atau indikator pembelajaran yang memuat tentang lingkungan. Upaya tersebut bukan merupakan sesuatu yang mustahil mengingat semua itu tergantung dari kemampuan guru menyiapkan materi dan melaksanakan pembelajaran dengan optimal. Upaya untuk memupuk kepedulian terhadap lingkungan sekolah diaplikasikan melalui Program kerja K3 (Kebersihan, Keindahan, dan Kerapihan) yang dilaksanakan di sekolah. Program K3 perlu terus dikembangkan sehingga pengembangan pendidikan karakter pada diri siswa yang mampu terbentuk dari dasar untuk meningkatkan kemandirian serta tanggung jawab. Dengan begitu kegiatan ini bertujuan untuk melakukan revitalisasi bank sampah sekolah dalam mendesain model pendidikan lingkungan berkelanjutan berbasis teknologi tepat guna.

\section{TINJAUAN LITERATUR}

\section{Konsep Revitalisasi Bank Sampah}

Revitalisasi adalah upaya untuk memvitalkan kembali suatu kawasan atau bagian kota yang dulunya pernah vital/hidup, akan tetapi kemudian mengalami kemunduran/degradasi. Skala revitalisasi ada tingkatan makro dan mikro. Proses revitalisasi sebuah kawasan mencakup perbaikan aspek fisik, aspek ekonomi dan aspek sosial. Pendekatan revitalisasi harus mampu mengenali dan memanfaatkan potensi lingkungan. Revitalisasi sendiri bukan sesuatu yang hanya berorientasi pada penyelesaian keindahan fisik saja, tapi juga harus dilengkapi dengan peningkatan ekonomi masyarakatnya serta pengenalan budaya yang ada. Untuk melaksanakan revitalisasi perlu adanya keterlibatan masyarakat. Keterlibatan yang dimaksud bukan sekedar ikut serta untuk mendukung aspek formalitas yang memerlukan adanya partisipasi masyarakat, selain itu masyarakat yang terlibat tidak hanya masyarakat di lingkungan tersebut saja, tapi masyarakat dalam arti luas. (Laretna, 2002) Pentingnya kesadaran akan lingkungan dapat dibentuk melalui pendidikan lingkungan berkelanjutan. 
Kondisi lingkungan sekolah memerlukan perhatian dari warga masyarakat, pimpinan sekolah, guru, tenaga administrasi, dan siswa. Lingkungan sekolah harus menjadi tempat yang nyaman untuk kegiatan pembelajaran, baik di dalam maupun di luar kelas. Kondisi ini dapat meningkatkan citra dan profil sekolah menjadi lebih baik. Sekolah sebagai sebuah institusi tidak hanya menjadi tempat transfer ilmu pengetahuan secara teoretik tetapi juga mampu menjadi tempat untuk menempa siswa melakukan tindakan dan pemikiran yang bersifat aplikatif dalam kehidupan sehari-hari, di tengah kehidupan masyarakat. Untuk itu peran guru tidak dapat dilepaskan dari proses pelaksanaan kebijakan pemerintah dalam bidang pembelajaran.

Permasalahan lingkungan tidak hanya berfokus pada pengembangannya saja tetapi dasar untuk menyelesaikan masalah lingkungan adalah pengetahuan dan pendidikan tentang lingkungan hidup (Valderrama-Hernández, Alcántara, \& Limón, 2017). Salim (2010: 204) menilai bahwa kesadaran lingkungan akan menumbuhkan rasa cinta alam sekaligus meningkatkan ketaqwaan kepada Tuhan Yang Maha Esa sebagai pencipta alam. Penyertaan peserta didik dalam pengembangan lingkungan hidup tidak penting untuk pembangunan berkelanjutan, tetapi juga sangat penting untuk pembentukan watak bangsa Indonesia yang senantiasa menyelaraskan hidup antara manusia dengan manusia, manusia dengan alam, dan manusia dengan Tuhan Yang Maha
Esa. Proses ini menujukkan telah tumbuhnya etika dalam keseharian di lingkungan sekolah (Keraf, 2004)

Status sekolah dikatakan sebagai sekolah yang baik apabila secara fisik, penataan lingkungan sekolah menampilkan unsur keindahan, kebersihan, suasana yang kondusif untuk melaksanakan proses pembelajaran, serta nyaman bagi siswa untuk bermain selama istirahat. Untuk mewujudkan kondisi sekolah yang demikian tentunya harus ada kerjasama yang intensif antara pihak guru, siswa, dan tenaga administrasi sekolah. Penataan lingkungan sekolah yang tepat akan memberikan predikat yang baik kepada seluruh jajaran pendidik dan tenaga kependidikan terkait. Kerjasama antara guru mata pelajaran IPA, IPS, PKn, Agama, Prakarya dan Seni Budaya dengan Pendidikan Lingkungan Hidup menjadi salah satu bentuk jalinan profesionalisme guru dalam mengelola kondisi lingkungan sekolah. Djamarah (1996) menyebut guru profesional adalah guru yang mampu meningkatkan taraf kualitas pembelajaran. Pembelajaran yang dimaksud tidak hanya bersifat teoretis tetapi juga yang bersifat praktis dan menguasai enam strategi meningkatkan kualitas pembelajaran (Mulyasa, 2005).

Kondisi lingkungan di sekitar sekolah merupakan sumber belajar sehingga dapat menjadi bahan desain model pendidikan lingkungan berkelanjutan. Semua mata pelajaran dapat dikaitkan dengan sisipan materi atau indikator pembelajaran yang memuat tentang lingkungan. Upaya 
tersebut bukan merupakan sesuatu yang mustahil mengingat semua itu tergantung dari kemampuan guru menyiapkan materi dan melaksanakan pembelajaran dengan optimal. Upaya untuk memupuk kepedulian terhadap lingkungan sekolah diaplikasikan melalui Program kerja K3 (Kebersihan, Keindahan, dan Kerapihan) yang dilaksanakan di sekolah. Program K3 perlu terus dikembangkan sehingga pengembangan pendidikan karakter pada diri siswa mampu terbentuk dari dasar untuk meningkatkan kemandirian serta tanggung jawab.

\section{Pendidikan Lingkungan}

Peserta didik sebagai penerus kehidupan masa depan harus memahami kondisi lingkungan hidup mereka dan berpartisipasi dalam membentuk lingkungan berkelanjutan. Penanaman nilai lingkungan utama dapat diterapkan di sekolah dengan membangun kesadaran untuk menjaga, merawat, serta mengembangkan lingkungan terdekatnya, yakni sekolah.

Menurut Archie

Pendidikan lingkungan juga meningkatkan pemikiran kritis peserta didik, sikap kepemimpinan, kompetensi, pemecahan masalah, keterlibatan akademik dan gaya hidup sehat. Salah satu manfaat dari pendidikan lingkungan adalah ketika peserta didik telah mampu mengelola lingkungan.

\section{METODE PELAKSANAAN}

Metode pendekatan dirancang dengan selalu memperhatikan keterlibatan mitra, dengan menentukan tahapan sebagai berikut:

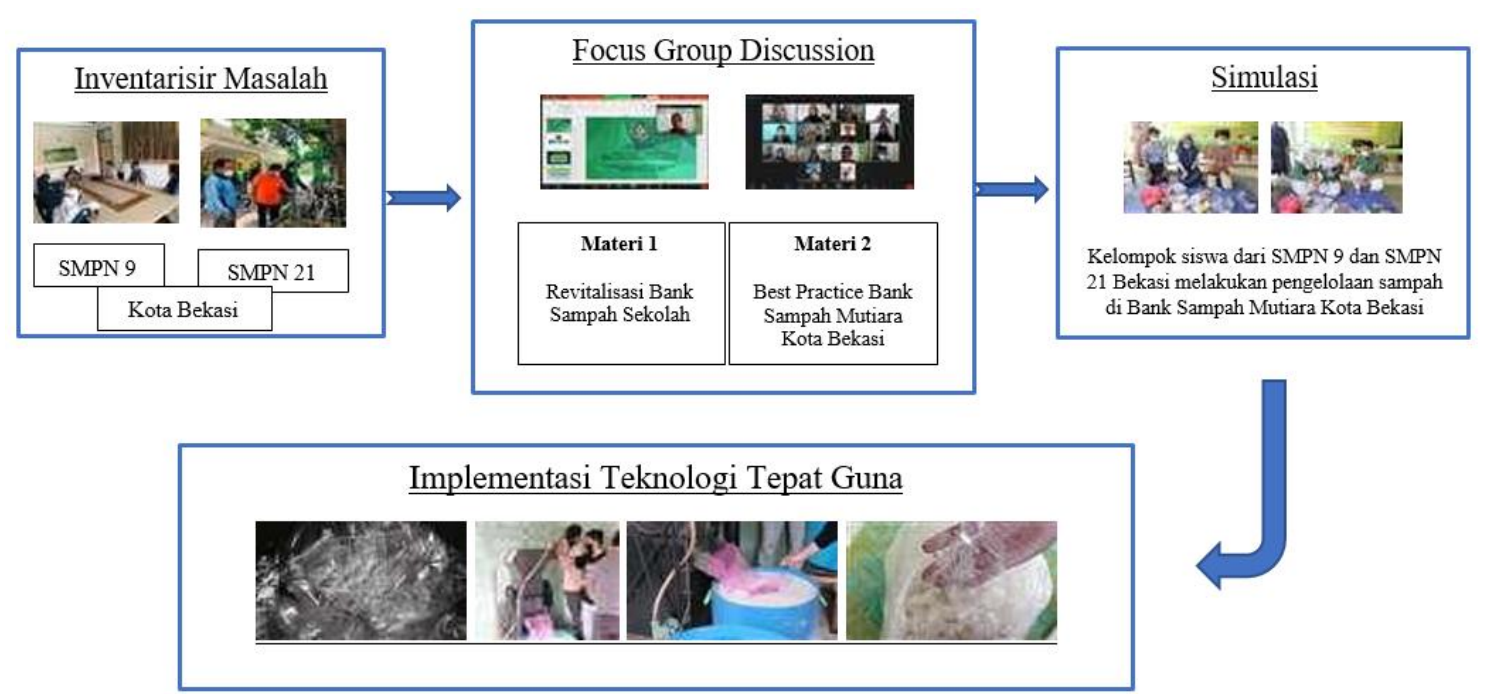

Gambar 1. Prosedur Pemecahan Masalah

Metode pelaksanaan berupa observasi dan FGD yang dilakukan di SMP Negeri 9 dan SMP Negeri 21 Kota Bekasi. Melalui kegiatan ini dirumuskan berbagai permasalahan yang dialami oleh SMP Negeri 9 dan SMP Negeri 21 Kota Bekasi dalam mengaktifkan kembali program bank sampah sekolah. 
Kegiatan selanjutnya yaitu dengan melibatkan mitra secara penuh untuk melakukan simulasi pemilahan sampah sampai pada pengenalan proses pencacahan botol plastik.

\section{HASIL DAN PEMBAHASAN}

Pelaksanaan FGD dengan SMP

Negeri 9 Kota Bekasi dilaksanakan pada tanggal 31 Juli 2021. Dalam pelaksanaan kegiatan FGD dipaparkan bahwa guru juga memiliki andil dalam upaya mengoptimalkan pengelolaan sekolah berbasis lingkungan. dan tema sekolah berbasis lingkungan menjadi budaya baru dalam kegiatan pengelolaan lembaga-lembaga pendidikan di berbagai wilayah Indonesia, dengan mengangkat kepedulian siswa terhadap kebersihan, keindahan, dan upaya-upaya pemeliharaan lingkungan hidup, baik di dalam maupun di sekitar sekolah. Usaha mengembangkan kepedulian tersebut tidak lain karena dewasa ini keperdulian masyarakat terhadap lingkungan fisik di sekitar kita sangat rendah. Dengan demikian akan berpengaruh pula terhadap kondisi lingkungan baik secara fisik maupun sosial budaya. Setelah berdiskusi dalam forum FGD antara UNJ dan Mitra sekolah didapati beberapa permasalahan mitra yang dapat diinventarisir setelah dilakukan pertemuan pendahuluan dan disepakati oleh Mitra antara lain:

1. Adanya stigma bahwa pengelolaan lingkungan semata-mata atas otoritas Kepala Sekolah.

2. Adanya pemahaman yang berorientasi bahwa program K3 hanya milik pengurus OSIS dan guru tertentu.

3. Pemahaman guru tentang pengelolaan lingkungan terkungkung oleh pemikiran seakan harus dilakukan oleh sekolah Adiwiyata.

4. Belum adanya struktur kepengurusan ekstrakulikuler lingkungan di sekolah.

Tahap pelaksanaan kegiatan pengabdian dimulai pada tanggal 11 September 2021 melalui zoom meeting. Pada pelaksanaan zoom meeting dipaparkan materi pertama oleh Dr. Budiaman, M.Si terkait revitalisasi bank sampah sekolah untuk mendesain pendidikan lingkungan berbasis teknologi tepat guna. Setelah materi pertama disampaikan kemudian dilanjutkan dengan tanya jawab.

Pada sesi materi kedua disampaikan oleh Aam Amaningsih Jumhur, P.hD terkait best practice Bank Sampah Mutiara Kota Bekasi. 


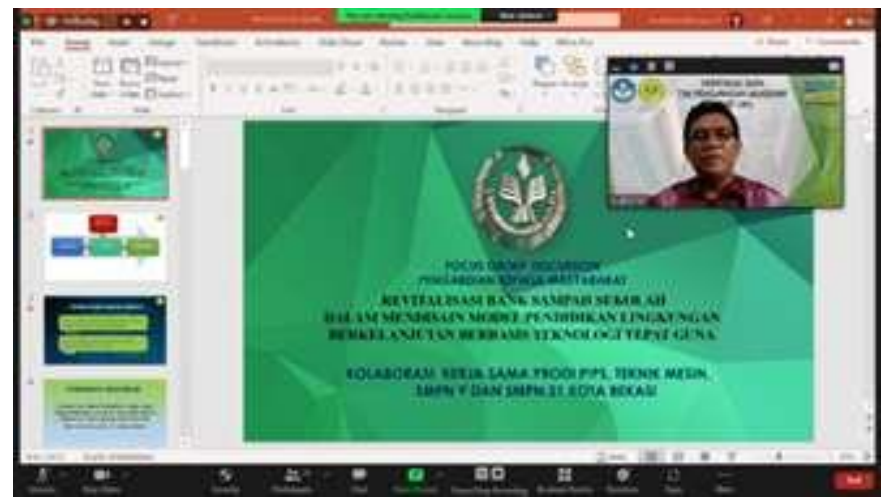

Gambar 2. Pemaparan Materi I oleh Dr. Budiaman, M.Si

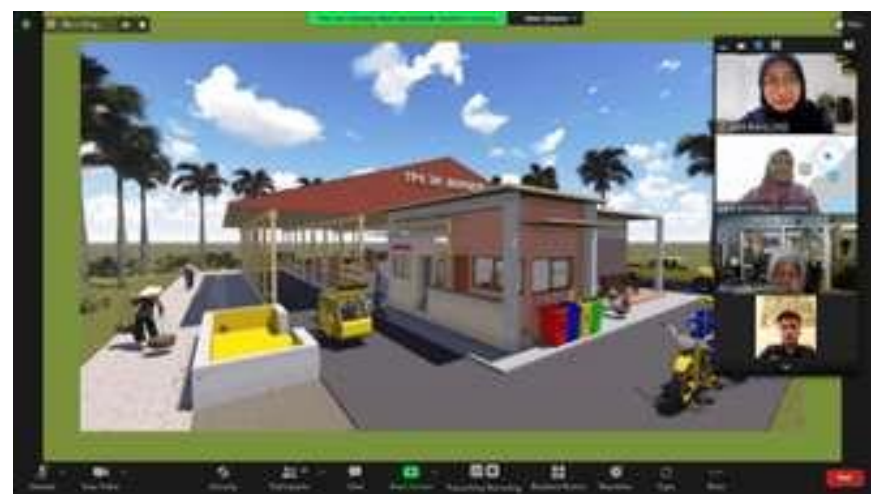

Gambar 3. Pemaparan Visual Materi II oleh Aam Amaningsih Jumhur, P.hD

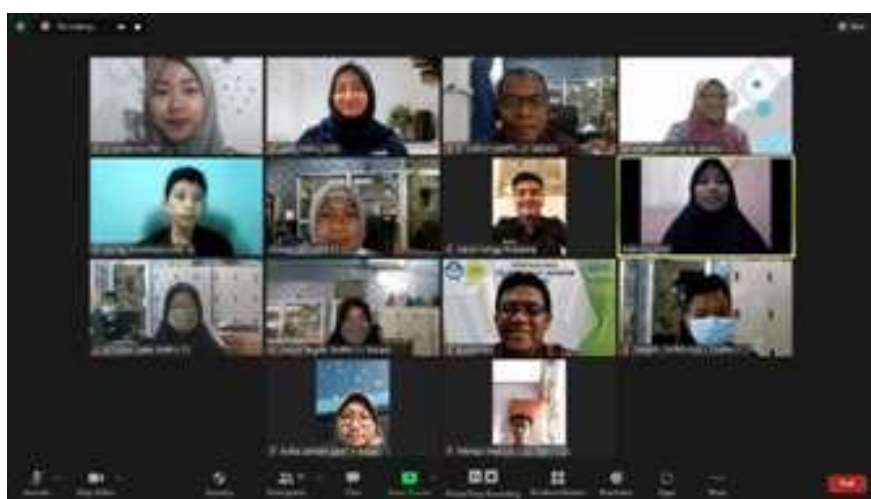

Gambar 4. Dokumentasi kegiatan bersama peserta

Kegiatan selanjutnya dilaksanakan kunjungan ke Bank Sampah Mutiara Kota Bekasi pada tanggal 18 September 2021. Kegiatan diawali dengan sambutan dari Ketua Pelaksana dan Pimpinan dari SMP Negeri 9 dan SMP Negeri 21 Kota Bekasi. Siswa/siswi SMP Negeri 9 dan SMP Negeri 21 Kota
Bekasi mendapatkan penjelasan dan simulasi langsung dari pengelola Bank Sampah Mutiara. Ketua pengelola menjelaskan tentang bagaimana proses pengelolaan bank sampah mulai dari kedatangan nasabah sampai proses pencacahan botol plastik. Secara rinci pengurus bank sampah yang lain 
menjelaskan tentang klasifikasi jenisjenis sampah berikut contohnya. Klasifikasi sampah seperti plastik bening, emberan, alumunium, besi, boncos, asoy, gelas platik, botol plastik, kaleng, duplek, kardus, dan kertas putih. Pengelola bank sampah meminta kelompok siswa dari SMP Negeri 9 dan
SMP Negeri 21 menunjukan kemampuannya dalam memilah jenisjenis sampah beserta contohnya. Kesempatan pertama diberikan kepada kelompok SMP Negeri 9 Kota Bekasi untuk menunjukan pengetahuannya tentang jenis-jenis sampah dan contohnya.
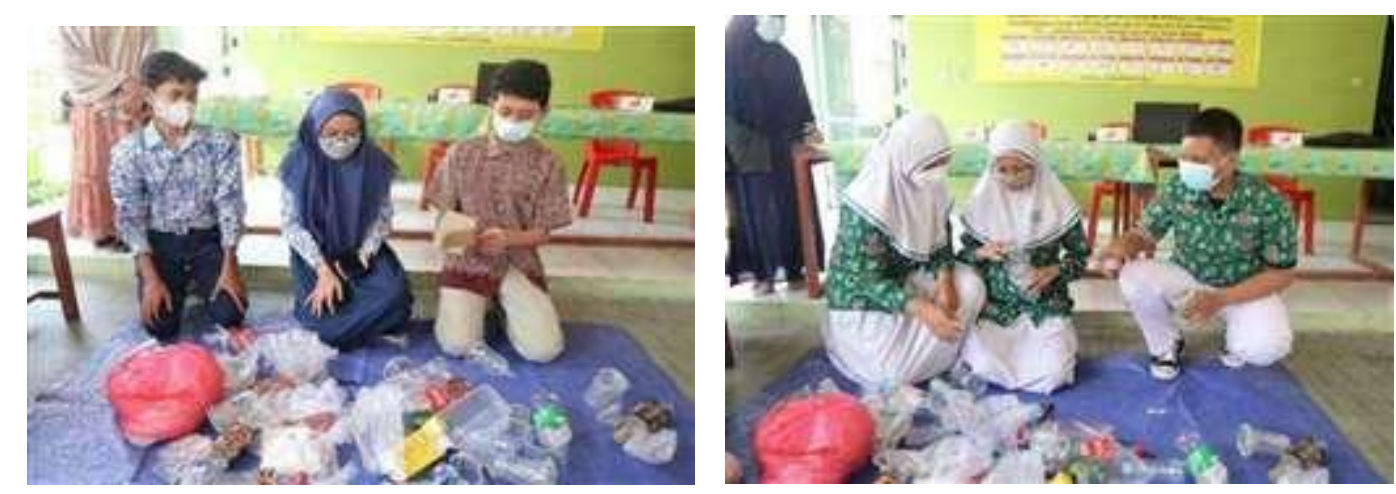

Gambar 5. Praktik pengelompokan sampah oleh Siswa SMP Negeri 9 dan SMP Negeri 21 Kota Bekasi
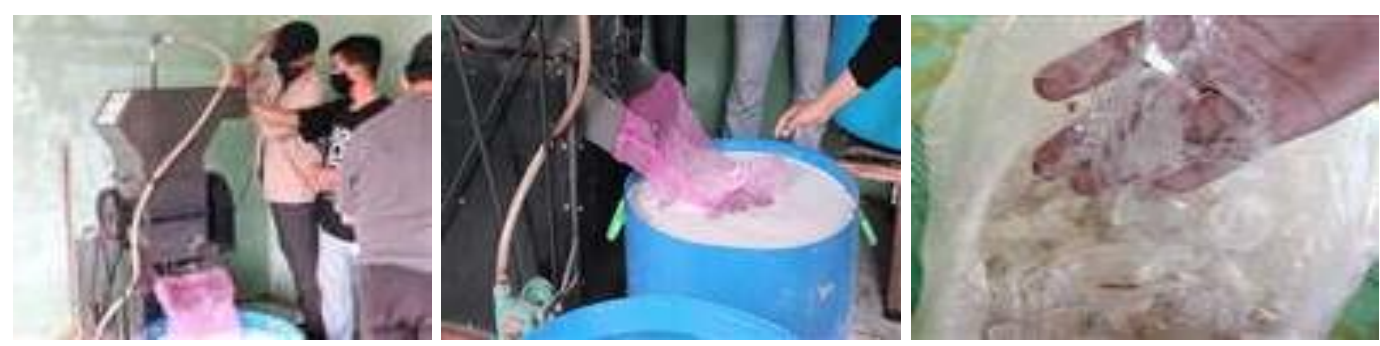

Gambar 6. Proses pengolahan sampah botol plastik menggunakan mesin pencacah botol plastik.

Dari kegiatan ini, kelompok siswa tidak hanya mengetahui jenis-jenis sampah tetapi juga dikenalkan bagaimana proses pengolahannya. Dalam hal ini proses pengolahan dengan menggunakan mesin pencacah plastik sebagai implementasi dari teknologi tepat guna untuk model pembelajaran lingkungan berkelanjutan di sekolah. Selain dapat mengurangi sampah di lingkungan, kegiatan bank sampah ini juga memiliki nilai ekonomis. Sampah yang telah dipilah dan dibersihkan dapat dijual dengan harga yang bervariatif sesuai dengan jenis sampahnya. Sampah plastik dengan harga tertinggi untuk industri adalah sampah botol plastik yang telah dicacah dengan baik seperti pada gambar 6 . 


\section{PENUTUP}

\section{Kesimpulan}

Kebersihan lingkungan sekolah yang terbebas dari sampah pada umumnya merupakan harapan dari pimpinan sekolah, guru, tenaga kependidikan, dan siswa. Kondisi tersebut dapat menjadi sumber belajar pendidikan lingkungan dan dimanfaatkan secara berkelanjutan. Semua mata pelajaran dapat dikaitkan dengan sisipan materi atau indikator pembelajaran yang memuat nilai-nilai kesadaran lingkungan. Upaya tersebut bukan merupakan sesuatu yang mustahil mengingat semua itu tergantung dari kemampuan guru menyiapkan materi dan melaksanakan pembelajaran dengan optimal. Upaya untuk memupuk kepedulian terhadap lingkungan sekolah diaplikasikan melalui Program kerja K3 (Kebersihan, Keindahan, dan Kerapihan) yang dilaksanakan di sekolah.

Kesadaran lingkungan siswa akan semakin terbentuk melalui revitalisasi bank sampah yang dimiliki SMP Negeri 9 dan SMP Negeri 21 Kota Bekasi. Selama ini, terutama masa pandemik, bank sampah kedua sekolah tidak berfungsi lagi, termasuk kelompok siswa pengelola kegiatan ekstra kurikuler lingkungan tidak dapat melaksanakan aktivitas secara optimal.

Kegiatan Pengabdian Kepada Masyarakat terintegrasi Kuliah Kerja Nyata (PKM-KKN) yang diorientasikan pada revitalisasi bank sampah sekolah memiliki fungsi strategis untuk menanamkan kesadaran lingkungan secara berkelanjutan. Pelaksana kegiatan
PKM-KKN merancang kegiatan dengan serangkaian kegiatan yang sistematis dan berkelanjutan. Kegiatan FGD, pendalaman materi, dan simulasi pengolahan sampah di Bank sampah yang sudah mandiri secara nyata memberikan motivasi bagi pimpinan sekolah, pembina ekstrakurikuler, dan siswa pengurus ekstra kurikuler yang dari masing-masing sekolah. Harapan akhir dari kegiatan ini setiap sekolah dapat mengaktifkan kembali bank sampah sekolah dan merestrukturasi pengurus ekstra kurikuler peduli lingkungan.

\section{Saran}

Berdasarkan pelaksanaan kegiatan yang melibatkan mitra SMP Negeri 9 dan SMP Negeri 21 Kota Bekasi dan Koperasi Bank Sampah Mutiara Surya Mandala Kota Bekasi, dapat direkomendasikan beberapa sara sebagai berikut:

1. Pimpinan sekolah diharapkan dapat menentukan kebijakan pengelolaan lingkungan terutama pengaktifan kembali bank sampah dan sarana dan prasarana pendukung.

2. Pembina ekstrakurikuler peduli lingkungan mengoptimalkan program-program yang selama ini sudah berjalan dengan baik selama menjadi sekolah adiwiyata.

3. Pengurus kegiatan ekstrakurikuler untuk dapat melakukan prestrukturisasi kepengurusan dan kaderisasi kepada pengurus yang sekarang dan berikutnya. 


\section{DAFTAR PUSTAKA}

Adisakti, Laretna. 2002. Revitalisasi Kawasan Pusaka di Berbagai Belahan Bumi. Harian Kompas.

Aplikasia, Jurnal Aplikasi llmu-ilmu Agama, Vol. VI, No. 1 Juni 2005:1-13 Pendekatan Andragogi dalam Pengembangan Masyarakat, hal. 9.

Djamarah, Syaiful Bahri. 2013. Strategi Belajar Mengajar. Jakarta: Rineka Cipta.

Jurnal Pendidikan dan Pemberdayaan Masyarakat Volume 2 Nomor 2, November 2015, (226 - 238) hal. 2.

Keraf, Sony. 2006. Etika Lingkungan. Jakarta: Kompas.

M. Archie, Advancing education through environmental literacy. Alexandria, VA: Association for Supervision and Curriculum Development, 2013
Mulyasa, Endang. 2005. Menjadi Guru yang Profesional. Bandung: Remaja Rosdakarya.

Nugraha, Adrian R. 2010. Menyelamatkan Lingkungan Hidup dengan Pengelolaan Sampah. Jakarta: PT. Cahaya Pustaka Raga.

Salim, Emil. 2010. Ratusan Bangsa Merusak Satu Bumi. Jakarta: Kompas.

Valderrama-Hernández, R., Alcántara, L., \& Limón, D. 2017. The Complexity of Environmental Education: Teaching Ideas and Strategies from Teachers. Procedia - Social and Behavioral Sciences, 237 Juni 2016. hal. 968-974.

Yudiyanto, dkk. 2019. Pengelolaan Sampah. Metro: Sai Wawai Publishing. 